\title{
Antecedents and Mediator of Turnover Intention amongst Employees in Private Communications Sector in Jordan: A Structural Equation Modeling (SEM) Approach
}

\author{
Khaldoun Khawaldeh ${ }^{1}$, Ayed M. Al Muala ${ }^{1} \&$ Mamdouh T. AL Ziadat ${ }^{1}$ \\ ${ }^{1}$ Applied Science University, Jordan \\ Correspondence: Ayed M. Al Muala, Applied Science University, Jordan. E-mail: aied_muala@yahoo.com
}

Received: July 2, 2013 Accepted: August 7, 2014 Online Published: August 29, 2014

doi:10.5539/jms.v4n3p135 URL: http://dx.doi.org/10.5539/jms.v4n3p135

\begin{abstract}
High employee turnover rate is a central problem in many organizations. This study's aim is to examine the relationship among job satisfaction, organizational commitment, and turnover intention of employees. A model of job satisfaction, organizational commitment, and turnover intention is developed and tested in one field study. In this study, using a 150 employees of a Jordanian communications (Orange) company, were given questionnaires to complete during regular working hours; 150 completed questionnaires were returned. Each variable was measured using reliable developed scales: job satisfaction (5 items), adapted from (Yücel, 2012), organizational commitment (12 items) by (Allen, \& Meyer, 1990, 1993; Yücel, 2012), and turnover intention (3 items) by (Lance, 1988; Yücel, 2012). Data was input into SPSS and analyzed used Structural equation modeling to test research hypotheses is used and the model that has high reliability and validity is developed. Amos results indicate that there some hypotheses: results of this study were as follows: H1 show that: organizational commitment was insignificant on turnover intention, and for $\mathrm{H} 2$ show that job satisfaction significant impact on turnover intention. In addition, $\mathrm{H} 3$ show that the job satisfaction was insignificant on organizational commitment. Finally, $\mathrm{H} 4$ show that the organizational commitment not mediates the relationship between job satisfaction and turnover intention of employees.
\end{abstract}

Keywords: job satisfaction, organizational commitment, turnover intention, communications, Jordan

\section{Introduction}

Jordanian business organizations facing several challenges in all areas of industrial, commercial and service, because Jordan is characterized by the presence of the open market toward the world and its accession to the WTO and face hard competitive, and this imposes a challenge to remove from the Their competitiveness. However, that it could face competition in the local market and international markets and this puts great pressure on senior management responsible for those organizations, since they have to operate on the proper use of available resources and high levels of quality performance. Previous studies suggested that job satisfaction has a significant and positive relationship with all dimensions of organizational commitment (Bagozzi, 1980; Reichers, 1985). In contrast, the relationship between organizational commitment and job satisfaction are jointed variables affecting negative results such as turnover intention (Shore and Martin, 1989; Yücel, 2012). Furthermore, Jordan is facing problem of high turnover rate among private communication sector professional (PCSP), the leave Jordanian PCSP services to start their own firms or to turnover to private sector. Likewise, Jordan private professional sector have a high turnover than non-professional, the most important reasons the salary in PCS still below an employee expectation, while other companies paid better in the private sector. The increased competition between organizations, and increase competitiveness in the global market makes it necessary to provide staff with the knowledge, given the importance than ever to ensure the effectiveness of the organization.

The private sector in Jordan has invested millions since entering the service of cellular communications Jordan in 1995. They also confirmed the absence of legal grounds on which the idea of licensing the third generation of them, along with the absence of logic in building on the study took place in 2003 at about the reality of the market, which changed both in terms of number of operators, or prevalence rate, or the degree of competition, or even price level (alrai, 2008). In 2008 worked in the market for cellular communications companies Zine "Fast Link previously and "Orange" Mobile Com previously, and Umniah along with the company Express mobile 
radio services, where do these companies combined base of subscribers is estimated at about 4.7 million subscribers, by Proliferation of more than $80 \%$, reinforced by low rate of return of a single common market to around 10 dinars (alrai, 2008). Therefore, Turnover intention, organization commitment and job satisfaction have been focus of many industrial and organizational psychologists, management and scientists. Furthermore, few studies have focused on employees' behavior in communication settings (Jeroen et al., 2007; Vivien and Thompson, 2009). It gives an idea that the employee's' behavior is not important for academic studies to investigating the factors that influence on employee's behavior.

It is important to ensure that understanding employee's' behavior is crucial for both employees themselves and organizations settings. Thus, the communications ministry wants to understand the employee's' behavior and what might influence their job conditions. Meanwhile, the decision makers in the ministry of communications, services providers have to be aware of employee's' behavior despite their location in order to do whatever necessary to meet their expectations (Pearce, 2005).

\section{Literature Review}

A high rate of employee turnover in an organization means increased recruiting, selection, and training costs. Have remaining as the primary variables effect on employee turnover behavior as job satisfaction, organization commitment absenteeism, employee ownership and researcher suggested training also effect on employee turnover (Schwab, 1991). Turnover intention, organization commitment, job satisfaction and organization satisfaction have been focus of many industrial and organizational psychologists, management and scientists. The key conceptual distinction between satisfaction, commitment, and turnover is that the first two concepts are employee attitudes or "orientations", but turnover refers to an employee behavior (Douglas B. Currivan, 1999). General Definitions Employee turnover occurs when employees, hired by the organization to perform a service, leave the organization. Employee departures may be voluntary or involuntary (Abbasi \& Hollman, 2000). Research in employee turnover is primarily concerned with voluntary turnover defined as "individual movements across the membership boundary of a social system which is initiated by the individual" (Price, 1977).

In recent models, job satisfaction (defined as degree to which employees have a positive affective orientation towards employment by the organization; Price, 1997) and organizational commitment (defined as loyalty to a social unit; Price, 1997). This study contributes to our understanding of the turnover process by specifying more precise assumptions about the relationship between satisfaction, commitment, while the emphasis in this study is on the causal relationship between satisfaction and commitment in communications sector. However, the planning for human resource, commitment and of staff powerful tool that leads to the success of organization. Therefore, the most important goals of the organizations is overcome the competitors and provide better services to the client, interested organizations to develop a strategy for well-trained work force vital to improve the production rate, the new professional in need of professional qualification, external courses to learn the experience of others. Development of new service requires staff training on how to use and provide to consumers (Priti Jain, 1999).

According to Kim, Leong, Yong (2005) job satisfaction is the extent to which a worker feels positively or negatively. Job satisfaction refers to the employees' general affective evaluation of their job. In the communication industry, job satisfaction helps to ensure that employees will treat customers with the utmost respect, because the importance of customer contact in developing relationships with customers, employees' job satisfaction is a primary concern for communication organizations that rely upon a loyal clientele. In general, job satisfaction leads to good employee performance, which, in turn makes them less likely to leave. According to Jerome and Kleiner (1995) stated that companies that exhibited high commitment to improving the employees' job satisfaction, motivation, and morale may realize long-term benefits of corporate success, loyalty, productivity, and employee retention. Job satisfaction has positive association with organizational commitment, employees who are satisfied with their jobs have greater organizational commitment than do dissatisfied employees (Kim et al., 2005).

According to Victoria Bellou, (2008) identify commitment as "a psychological state that binds the individual to the organization", that comprises of three dimensions (affective, continuance, and normative commitment). In addition, among the positive outcomes of organizational commitment is employee intention to remain at the organization, organizational commitment as an attachment to or identification with the organization. Such an attachment may be considered an emotional response, particularly when the individual believes strongly in the organization's goals and values and/or demonstrates a strong desire to maintain membership in the organization (Kim et al., 2005). Similarly, common limitations in research design of previous studies of the turnover process 
have prevented researchers from conducting appropriate analysis, and drawing precise conclusions, on the causal relationship between satisfaction and commitment.

Intention of leaving is an important outcome in the behavior of communication employees. Although intention of leaving is an undesirable outcome for organizations, it is valuable to understand its predictors in order to minimize its negative impact on an organization's effectiveness. To reduce the turnover rate in the communication industry, the firm must be sensitive to the intrinsic motivational factors of employees (Kim et al., 2005). Woods and Macaulay (1989) stated that turnover was not an issue, since there was an abundant labor supply. However, the labor force is shrinking and this shrinkage brings about high turnover and poor customer service. The effects of turnover are related to a reduction in managerial readiness, loss of sales, and a decrease in the company's profits. Researchers have theorized that low levels of organizational commitment will lead to willingness to search for another job, intention of leaving, and turnover. Research results have shown that organizational commitment is negatively related to intention of leaving. The basic objective of this article is to posit the relationships among job satisfaction, organizational commitment and turnover intention.

Figure 1 depicts the conceptual framework of relationships among job satisfaction, organizational commitment, and turnover intention.

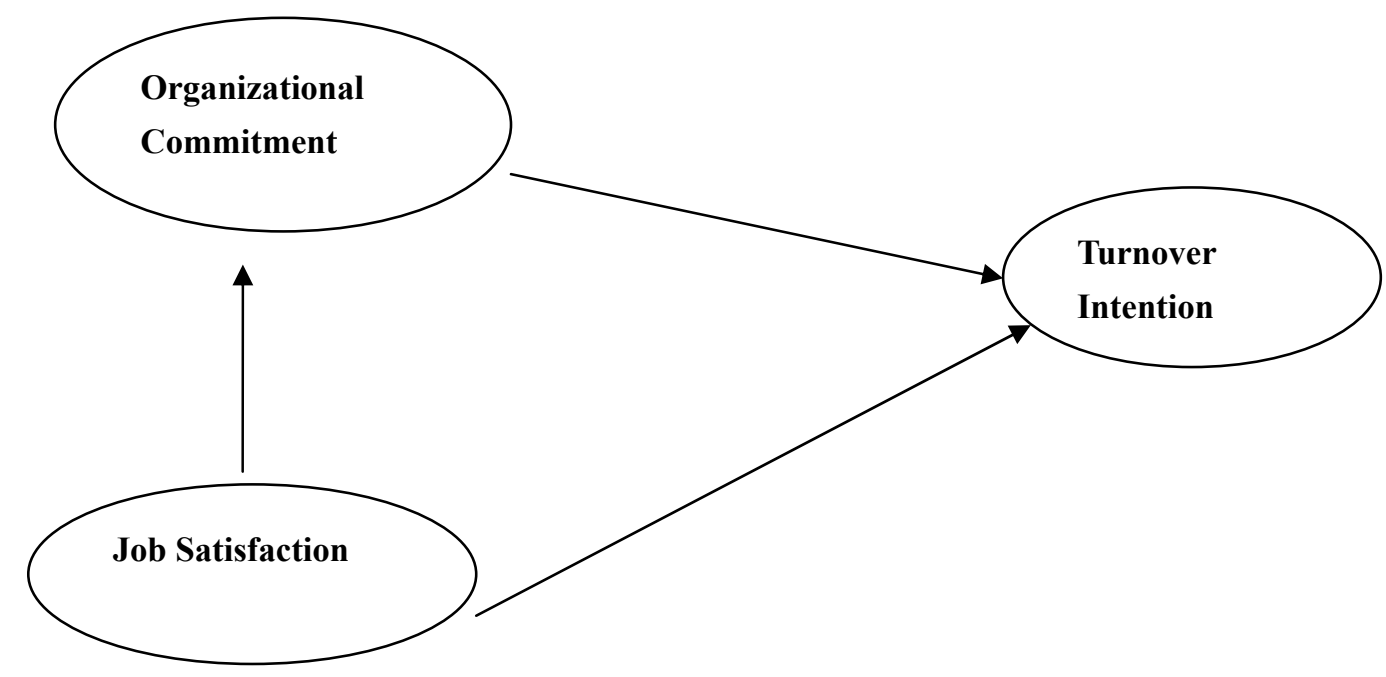

Figure 1. Model of study

\section{Hypotheses of the study}

There is a relationship between organizational commitment and job satisfaction on employee turnover intention in private Jordanian communication. This section includes the hypothesis information of this study as discussed below:

H1: organizational commitment is negatively related to turnover intention of employee.

$\mathrm{H} 2$ : Job satisfaction is negatively related to turnover intention of employee.

H3: Job satisfaction is positive related to organizational commitment.

H4: organizational commitment mediates the relationship between Job satisfaction and turnover intention of employee.

\section{Methodology}

This study utilizes quantitative research design to investigate the predictors of turnover intention of employees work in communications sector. The population of this study consists of employees in the Orange Company in Amman. This study selected employees due to some reasons. Firstly, it has been used in past studies (Allen \& Meyer, 1990, 1993; Yücel, 2012). Secondly, the employees can use the correct information regarding the model such as commitment dimensions and job satisfaction. Thirdly, employees inside Jordanian communications have fresh memories according to their experiences and reasons of employee's turnover. A systematic random sample was used in which 150 respondents were identified from 3 places in the capital of Jordan (Amman).The questionnaire is divided into four parts: part (1) demographic variables (12 items); part (2) job satisfaction (5 
items) adapted from Yücel (2012) and part (3) organizational commitment (12 items) adopted from (Allen \& Meyer, 1990, 1993; Yücel, 2012). Finally, part (4) turnover intention (3 items) adapted from (Lance, 1988; Yücel, 2012). Furthermore, this study used Structural Equation Modeling (SEM) by using Amos program instead of multiple regressions because SEM can give more goodness of Fit indices for the full structural model, giving more superior empirical results (Hair et al., 2006). All variables were measured using five-point Likert scales from (1) Strongly disagree, (2) Disagree, (3)Undecided, (4) Agree, (5) Strongly Agree.

\section{Results}

\subsection{Demographic Profile of the Respondents}

The respondents' ages ranged from 20 to more than 50 years old. There are more male respondents (21\%) compared to female (79\%). The majority was married (77\%). Finally, the majority of income was from $1000 \$$ to $2000 \$(60 \%)$.

\subsection{Reliability and Normality}

This study consists of two exogenous (organizational commitment and job satisfaction) and one endogenous variable (turnover intention) (Table 1). Each construct shows Cronbach alpha value of acceptable values of above 0.60 (Nunnally, 1970). Therefore, reliability values for all constructs are range from .81 to .99. This indicates that all constructs have acceptable internal consistency. In addition, 6 items remaining after confirmatory factor analysis CFA. The second test is the composite reliability of each measure (see Table 1). This was assessed using Nunnally (1970) guideline for assessing reliability coefficients. Composite reliability developed by Werts et al (1974), measures the reliability of a construct in the measurement model. The composite reliability is calculated by use of the following equation:

$$
\begin{gathered}
\text { Composite reliability }= \\
\frac{\left(\sum s \tan \text { dizedloding }\right)^{2}}{(\Sigma s \tan \text { dizedloading })^{2}+\sum \varepsilon j}
\end{gathered}
$$

Source: Hair et al. 1998:624.

In addition, a composite reliability index that exceeds 0.70 indicates satisfactory internal consistency (Hair et al., 1998).

Table 1. Descriptive statistics of variables

\begin{tabular}{llllllll}
\hline Construct & Original Items & Total Mean & $\begin{array}{l}\text { Standard } \\
\text { Deviation }\end{array}$ & $\begin{array}{l}\text { Items } \\
\text { CFA }\end{array}$ & $\begin{array}{l}\text { after } \\
\text { Cronbach } \\
\text { Alpha } \\
\text { CFA }\end{array}$ & $\begin{array}{l}\text { Composite } \\
\text { after }\end{array}$ \\
Reliability \\
Organizational commitment & 12 & 3.1 & .72 & 2 & .74 & .81 & .90 \\
Job satisfaction & 5 & 3.4 & .61 & 2 & .71 & .96 & .99 \\
Turnover intention & 3 & 3.2 & .92 & 2 & & & \\
\hline
\end{tabular}

The summary of the composite reliability based on the standardized factor loadings obtained from the final revised structural model, all constructs have acceptable value of above 0.60 (Nunnally, 1970) or exceeds 0.70 (Hair et al., 1998).

\subsection{Confirmatory Factor Analysis (CFA) Results}

Table 2 shows the confirmatory factor analysis results, which illustrates factor loadings of all observed variables or items are adequate ranging from 0.68 to 0.97 . In this study, the "cut-off" point chosen for significant loading is 0.40 , the minimum level required for a sample size of 150 and above as suggested by (Hair et al. 2006, p 128). This indicates that all the constructs conform to the construct validity test. 
Table 2. Final confirmatory factor analysis results of construct variables

\begin{tabular}{|c|c|c|c|}
\hline Construct & Code & Attributes & $\begin{array}{l}\text { Factor } \\
\text { Loading }\end{array}$ \\
\hline Organizational & OCC1 & Right now, staying with my organization is a matter of necessity as much & .84 \\
\hline \multirow[t]{2}{*}{ Commitment } & & as desire. & .71 \\
\hline & OCC2 & $\begin{array}{l}\text { It would be very hard for me to leave my organization right now, even if } \\
\text { I wanted to. }\end{array}$ & \\
\hline \multirow[t]{2}{*}{ Job Satisfaction } & JOS4 & Most days I am enthusiastic about my work. & .83 \\
\hline & JOS5 & I find real enjoyment in my work. & .68 \\
\hline \multirow[t]{2}{*}{ Turnover Intention } & TRN1 & I intend to leave the organization. & .97 \\
\hline & TRN2 & $\begin{array}{l}\text { I intent to make a genuine effort to find another job over the next few } \\
\text { months. }\end{array}$ & .96 \\
\hline
\end{tabular}

\subsection{Discriminant Validity of Constructs}

Discriminant validity is another major type of construct validity to test for multi-collinearity. It refers to whether observed constructs that are highly related to each other (Campbell \& Fiske, 1959; Gaski (1984)). Table 3 shows the result of the calculated variance extracted (VE) to support discriminant validity of constructs. Average variance extracted (AVE) is the average VE values of two constructs (Table 4). The AVE derived from the calculation of variance extracted using the following equation:

$$
\text { Variance Extracted }=\frac{\Sigma(s \tan \text { dardizedSMC })^{2}}{\Sigma(s \tan \text { dardizedSMC })^{2}+\Sigma \varepsilon j}
$$

Source: Hair et al., 1998:624.

Table 3. Variance extracted of variables

\begin{tabular}{lllll}
\hline Observed Variables & SMC & SMC2 & $\begin{array}{l}\text { Measurement } \\
\text { Error }\end{array}$ & $\begin{array}{l}\text { Variance } \\
\text { Extracted }\end{array}$ \\
\hline OCC1 & .49 & .24 & .14 & .71 \\
OCC2 & .26 & .07 & .14 & \\
Organizational Commitment(Total) & .75 & .31 & .28 & .76 \\
JOS4 & .68 & .46 & .10 & \\
JOS5 & .46 & .21 & .11 & .95 \\
Job Satisfaction(Total) & 1.14 & .67 & .21 & \\
TRN1 & .93 & .86 & .05 & .05 \\
TRN2 & .93 & .86 & .10 & \\
Turnover Intention(Total) & 1.86 & 1.72 & & \\
\hline
\end{tabular}

Table 4. Average variance extracted (AVE) matrix of exogenous variables

\begin{tabular}{lll}
\hline Variable Name & Organizational Commitment & Job Satisfaction \\
\hline Organizational Commitment & 1 & .74 \\
Job Satisfaction & .74 & 1 \\
\hline
\end{tabular}

Table 5. Correlation \& correlation square matrix among exogenous variables

\begin{tabular}{lll}
\hline Variables Name & Organizational Commitment & Job Satisfaction \\
\hline Organizational Commitment & 1 & $.68(.46)$ \\
Job Satisfaction & $.68(.46)$ & 1 \\
\hline
\end{tabular}

\subsection{Goodness of Fit Indices}

Confirmatory factor analysis was conducted for every construct and measurement models. Bagozzi and Yi (1988) point out that the measurement model has a good fit with the data based on assessment criteria such as GFI, CFI, TLI, and RMSEA. Table 6 shows that the goodness of fit of generated model is better compared to the 
hypothesized model. However, Hair et al (2006) point out that all CFAs of constructs produced a relatively good fit as indicated by the goodness of fit indices such as CMIN/DF ratio $(<2)$; goodness of fit Index (GFI) of $(>$ 0.90 ); P-value (>0.05); and root mean square error of approximation (RMSEA) of values less than 0.08 . Table 6 and figure 3 shows that the goodness of fit of generating model is better compared to the hypothesized model.

Table 6. Generating model and hypothesized model results

\begin{tabular}{lll}
\hline Indicators & Generating Model & Hypothesized Model \\
\hline CMIN & 10.275 & 612.650 \\
DF & 5 & 167 \\
CMIN/DF & 2.055 & 3.669 \\
P-value & .06 & .000 \\
RMSEA & .08 & .134 \\
CFI & .99 & .70 \\
TLI & .69 & .66 \\
IFI & .99 & .70 \\
\hline
\end{tabular}

\subsection{Hypotheses Results}

As shown in Figure 2 hypothesized model did not achieve model fit $(\mathrm{p}<.000)$, hence, the explanation of hypotheses result is based on Generating Model (GM) (Table 7 and Figure 3). Based on the finding (Table 7), Job satisfaction is negatively related to turnover intention (H2) supported). The other two hypotheses (H1 and H3) were not significant.

Table 7. Direct impact Generating Model (GM): Standardized regression weights

\begin{tabular}{lllllll}
\hline Hypothesis & From & To & Estimate & C.R & P & Hypothesis Support \\
\hline H1 & Organizational & Turnover Intention & -.15 & -.014 & .99 & NO \\
& Commitment & & & & & \\
H2 & Job Satisfaction & Turnover Intention & .83 & 4.7 & $* * *$ & YES \\
H3 & Job Satisfaction & Organizational & .83 & .014 & .99 & NO \\
& & Commitment & & & & \\
\hline
\end{tabular}

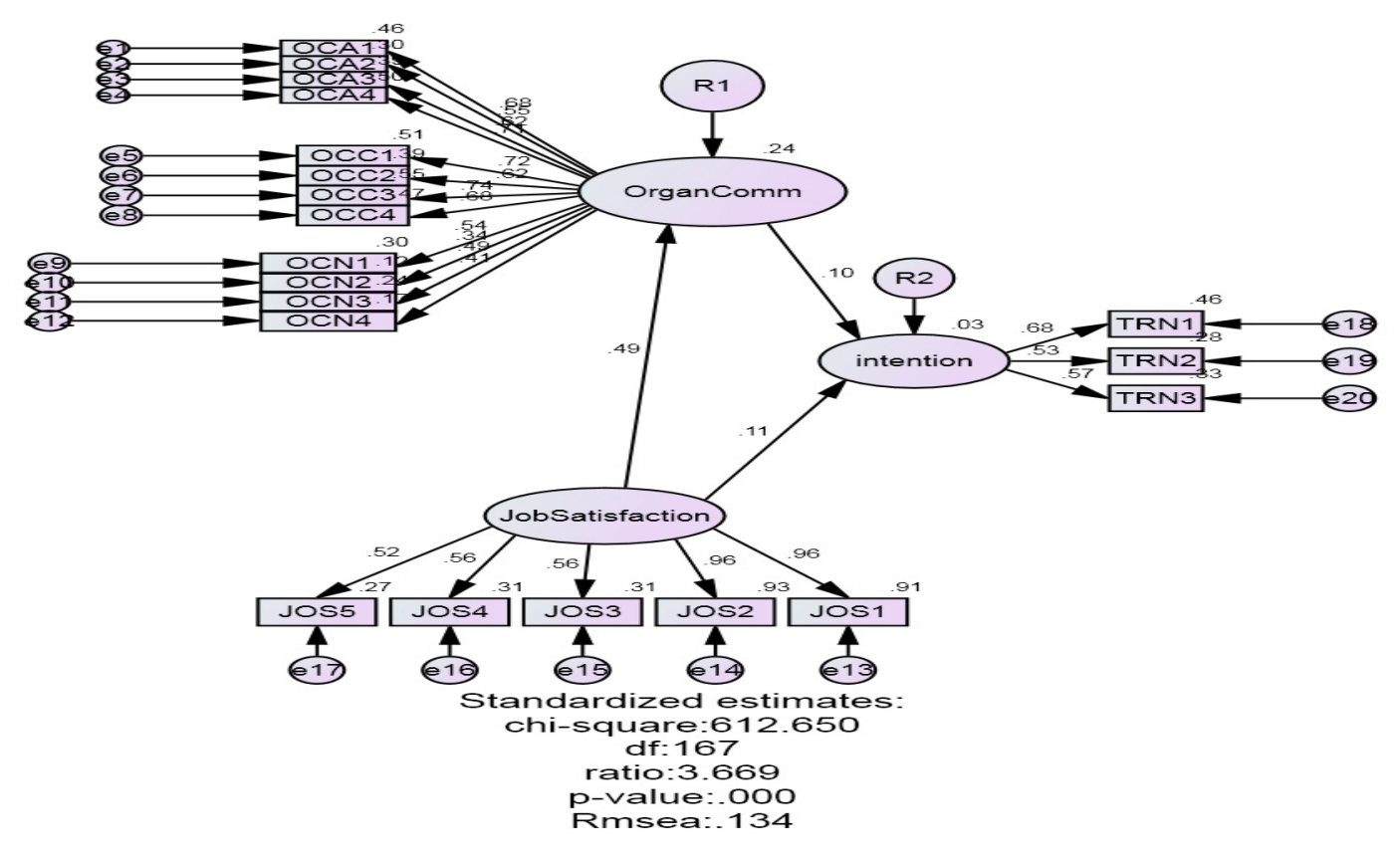

Figure 2. Hypothesized models 


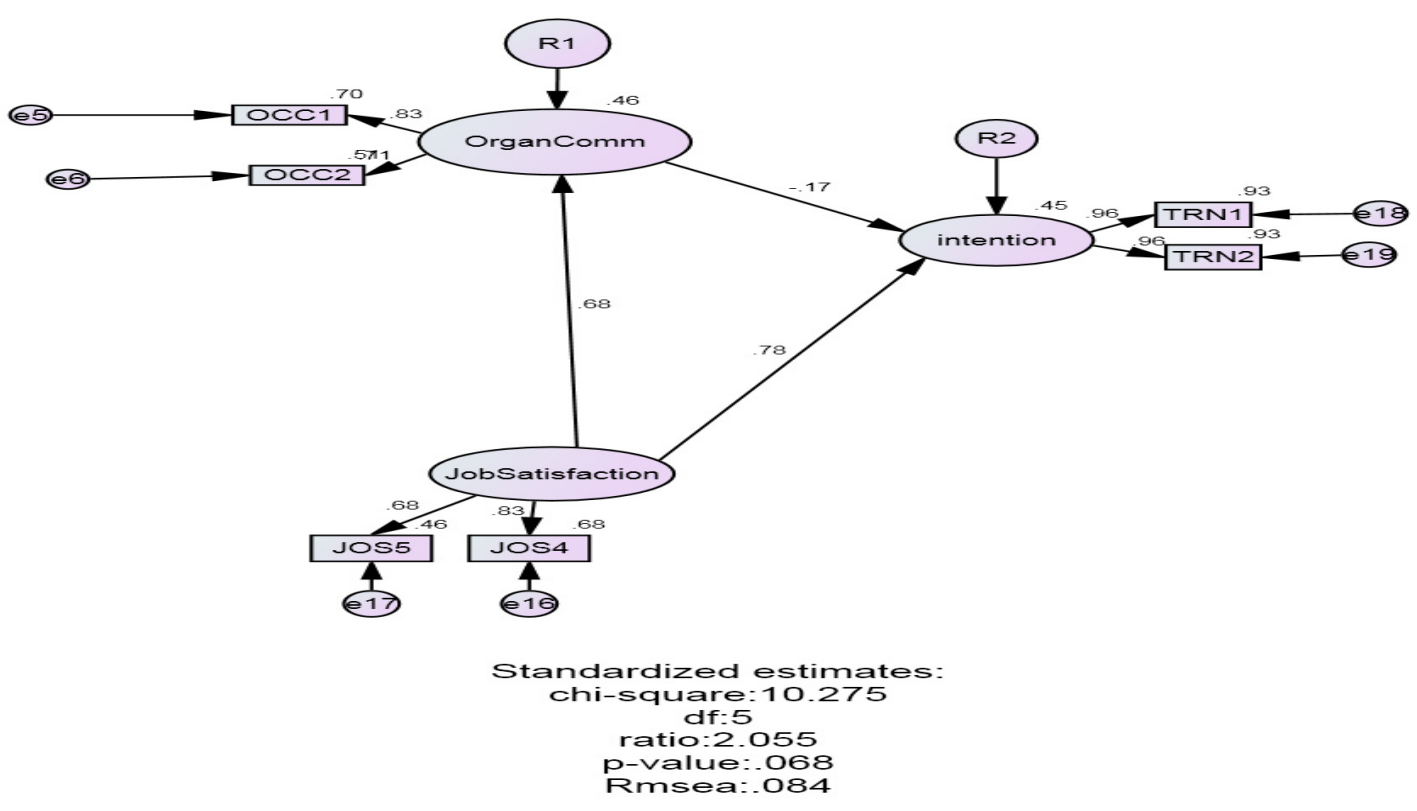

Figure 3. Generating Model (GM)

Table 8 indicate that the two exogenous variables (job satisfaction and organizational commitment) jointly explained $45 \%$ variance in turnover intention and job satisfaction explains $46 \%$ variance in organizational commitment.

Table 8. Squared multiple correlation results

\begin{tabular}{ll}
\hline Endogenous Variable & Squared multiple correlation $(\mathrm{SMC})=\mathrm{R} 2$ \\
Turnover Intention & .45 \\
Organizational Commitment & .46 \\
\hline
\end{tabular}

\subsection{Mediating Effect Analysis of Generating Model (GM)}

This study tested mediating effect of organizational commitment in the relationship between job satisfaction and turnover intention (H4) shows no mediating effect (see Table 1.9). This results because the relation between job satisfaction and organizational commitment not significant and the relationship between job satisfaction and turnover intention significant (see Table 7). In additionally, indirect effect less than direct effect, this that means that organizational commitment not mediating between job satisfaction and turnover intention.

Table 9. Mediating effect of organizational commitment

\begin{tabular}{|c|c|c|c|c|c|c|}
\hline Hypothesis & From & Mediation & To & $\begin{array}{l}\text { Direct } \\
\text { effect }\end{array}$ & $\begin{array}{l}\text { Indirect } \\
\text { effect }\end{array}$ & Mediating \\
\hline $\mathrm{H} 4$ & job satisfaction & $\begin{array}{l}\text { organizational } \\
\text { commitment }\end{array}$ & $\begin{array}{l}\text { turnover } \\
\text { intention }\end{array}$ & .78 & .12 & $\begin{array}{l}\text { Not } \\
\text { Mediating }\end{array}$ \\
\hline
\end{tabular}

\section{Discussion}

As mentioned earlier, this study attempts to examine the goodness of fit of the hypothesized structural model by integrating job satisfaction and organizational commitment. The hypothesized model does not achieve model fit ( $\mathrm{p}$-value $=0.000, \mathrm{p}<0.001)$. This implies that hypothesized model is not supported. However, the Generating Model (GM) accomplished model fits, thus, results could be generalized to the population. Job satisfaction has a 
direct negative significant impact on turnover intention. Past studies have obtained similar result (Mahdi, et al., 2012; Egan et al., 2004; Farrell and Rusbult, 1981) Thus, a negative relationship between Job satisfaction and turnover intention means that the employees have intent to leave the current work if they not satisfied in future.

In this sense, it should be emphasized on the communications sector to make employees' satisfaction a priority of its work. As well as, focus on the dimensions that contribute to the satisfaction of employees, such as training and participation in international conferences and monthly and annual incentives that contribute to the survival of the employees of the company for as long as possible. Second, organizational commitment have no relationship with turnover intention, past studies have obtained similar result (Masemola, 2011). Third, the relationship between job satisfaction and organizational commitment is not insignificant (positive relationship) which is similar to previous study (Suk and Suk, 2011).

\section{Suggestion for future research}

This study focuses of a Jordanian communications (Orange) company only. Future research should investigate the model in other companies and industries in Jordan such as on banking, tourism, and insurance. Other determinant factors need to be considered in future research such as technological factors (i.e. Internet), providing a services, incentives, environment factors, and infrastructure factors. More importantly, the Ministry of Jordanian communications should focus more on the safety, availability of modern facilities for employees and development of better transportations avenues that could help employees to have a faster access to all company sites.

\section{Conclusion}

This research examines the antecedents of turnover intention among employees using SEM. Job satisfaction is found to be negatively and significantly related to turnover intention while organizational commitments are not. Also, job satisfaction found positively and insignificant related to organizational commitments. The result also shows that the Generating Model (GM) is the best model to explain the satisfaction and commitment of employees to turnover intention as compared to the Hypothesized Models.

\section{Acknowledgements}

The authors are grateful to the Applied Science University, Amman, Jordan, for the financial support granted to this research project (Grant No:251/ع ب/19-5-2013).

\section{References}

Abbasi, S. M., \& Hollman, K. W. (2000). Turnover: The real bottom line. Public Personnel Management, 29(3), 333-342.

Allen, N. J., \& Meyer, J. P. (1990). The Measurement and Antecedents of Affective, Continuance and Normative Commitment to the Organization. Journal of Occupational Psychology, 63(1), 1-18. http://dx.doi.org/10.1111/j.2044-8325.1990.tb00506.x

Alrai. (2008). Government begins tour for meetings with telecommunications operators around the license (3rd generation). JORDAN PRESS FOUNDATION.

Bagozzi, R. P. (1980). Performance and Satisfaction in an Industrial Sales Forces: An Examination of Their Antecedents and Simultaneity. Journal of Marketing, 15(4), 65-67. http://dx.doi.org/10.2307/1249978

Bagozzi, R. P., \& Yi, Y. (1988). On the evaluation of structural equation models. Journal of the Academy of Marketing Science, 16, 74-94.

Campbell, D. T., \& Fiske, D. W. (1959). Convergent and Discriminant Validation by the Multi-trait, Multimethod Matrix. Psychological Bulletin, 56, 81-105. http://dx.doi.org/10.1037/h0046016

Currivan, D. B. (1999). The causal order of job satisfaction and organizational commitment in models of employee turnover. Human Resource Management Review, 9(4), 495-524. http://dx.doi.org/10.1016/S1053-4822(99)00031-5

de Jong, J. P. J., \& Hartog, D. N. D. (2007). How leaders influence employees' innovative behavior. European Journal of Innovation Management, 10(1), 41-64. http://dx.doi.org/10.1108/14601060710720546

Egan, T. M., Yang, B., \& Bartlett, K. R. (2004). The Effects of Organizational Learning Culture and Job Satisfaction on Motivation to Transfer Learning and Turnover Intention. Human Resource Development Quarterly, 15(3). http://dx.doi.org/10.1002/hrdq.1104 
Farrell, D., \& Rusbult, C. E. (1981). Exchange Variables as Predictors of Job Satisfaction, Job Commitment, and Turnover: The impact of rewards, costs, Alternatives, and Investment. Organiztional Behaviour and Human Performance, 27, 78-95. http://dx.doi.org/10.1016/0030-5073(81)90016-7

Gaski, F. M. (1984). The index of consumer sentiment toward marketing. Journal of Marketing Assessment, 50(3), 71-81. http://dx.doi.org/10.2307/1251586

Hair, J. F., Black, W. C., Babin, B. J., Anderson, R. E., \& Tatham, R. L. (2006). Multivariate Data Analysis (6th ed.). Prentice Hall.

Hair, J., Anderson, R., Tatham, R. L., \& Black, W. C. (1998). Multivariate data analysis (5th ed.). NJ: Upper Saddle River, Prentice-Hall.

Jerome, L., \& Kleiner, B. H. (1995). Employee morale and its impact on service: what companies do to create a positive service experience. Managing Service Quality, 5(6), 21. http://dx.doi.org/10.1108/09604529510104356

Kim, W. G., Leong, J. K., \& Lee, Y. K. (2005). Effect of service orientation on job satisfaction, organizational commitment, and intention of leaving in a casual dining chain restaurant. Hospitality Management, 24, 171-193. http://dx.doi.org/10.1016/j.ijhm.2004.05.004

Lance, C. E., Lautenschlager, G. T., Sloan, C. E., \& Varca, P. E. (1989). A comparison between bottom-up,top-down and bi-directional models of relationships between global and life facet satisfaction. Journal of Personality, 57, 601-624. http://dx.doi.org/10.1111/j.1467-6494.1989.tb00565.x

Mahdi, A. F., Mohd Zin, M. Z., Mohd Nor, M. R., Sakat, A., \& Naim, A. (2012). The Relationship between Job Satisfaction and Turnover Intention. American Journal of Applied Sciences, 9(9), 1518-1526. http://dx.doi.org/10.3844/ajassp.2012.1518.1526

Masemola, S. E. (2011). Employee turnover intentions, organisational commitment and job satisfation in a post-merger tertiary institution: the case of the University of Limpopo. Master of business administration (MBA), University of Limpopo South Africa.

Nunnally, J. (1970). Introduction to Psychological Measurement. New York: McGraw-Hill.

Pearce, P. (2005). Tourist behaviour: themes and conceptual scheme. Clevedon: Channel View.

Price, J. L. (1997). Handbook of organizational measurement. International Journal of Manpower, 18, 303-558. http://dx.doi.org/10.1108/01437729710182260

Price, J. L., \& Mueller, C. W. (1986). Absenteeism and turnover of hospital employees. In B. Bacharach (Ed.), Monographs in organizational behavior and industrial relations (Vol. 5). Greenwich, CON: JAI Press.

Priti, J. (1999). On-the-job training: a key to human resource Development. Library Management, 20(5), 283-294. http://dx.doi.org/10.1108/01435129910276271

Reichers, A. E. (1985). A Review and Reconceptualization of Organizational Commitment. Academy of Management, 10, 465-476.

Schore, L. M., \& Martin, H. J. (1989). Job Satisfaction and Organizational Commitment in Relation to Work Performance and Turnover Intentions. Human Relations, 42, 625-638. http://dx.doi.org/10.1177/001872678904200705

Schwab, D. P (1991). Contextual Variables in Employee Performance Turnover Relationship. Academy of Management Journal. http://dx.doi.org/10.2307/256400

Suk, N. M. (2011). Job satisfaction and organisational commitment: the effect of gender. International Journal of Psychology Research, 6(5), 1-15.

Victoria, B. (2008). Exploring civic virtue and turnover intention during organizational changes. Journal of Business Research, 61, 778-789. http://dx.doi.org/10.1016/j.jbusres.2007.09.001

Vivien, K. G. L., \& Thompson, S. H. (2009). Mind your E-manners: Impact of cyber incivility on employees' work attitude and behavior. Information \& Management, 46(8), 419-425. http://dx.doi.org/10.1016/j.im.2009.06.006

Werts, C. E., Linn, R. L., \& Joreskog, K. G. (1974). Interclass reliability estimates: testing structural assumptions. Educational and Psychological Measurement, 34, 325-347. http://dx.doi.org/10.1177/001316447403400104 
Woods, R. H., \& Macaulay, J. F. (1989). Rx for turnover: retention programs that work. Cornell Hotel and Restaurant Administration Quarterly, 30(1), 78-90. http://dx.doi.org/10.1177/001088048903000119

Yücel, I. (2012). Examining the Relationships among Job Satisfaction, Organizational Commitment and Turnover Intention: An Empirical Study. International Journal of Business and Management, 7(20). http://dx.doi.org/10.5539/ijbm.v7n20p44

\section{Copyrights}

Copyright for this article is retained by the author(s), with first publication rights granted to the journal.

This is an open-access article distributed under the terms and conditions of the Creative Commons Attribution license (http://creativecommons.org/licenses/by/3.0/). 